Document downloaded from:

http://hdl.handle.net/10251/99648

This paper must be cited as:

Lluís Pascual; El Sayed Shehata Nasr, S.; Marcos Martínez, MD.; Martínez-Máñez, R.; Sancenón Galarza, F. (2017). Acetylcholinesterase-capped Mesoporous Silica Nanoparticles Controlled by the Presence of Inhibitors. Chemistry - An Asian Journal. 12(7):775-784. doi:10.1002/asia.201700031

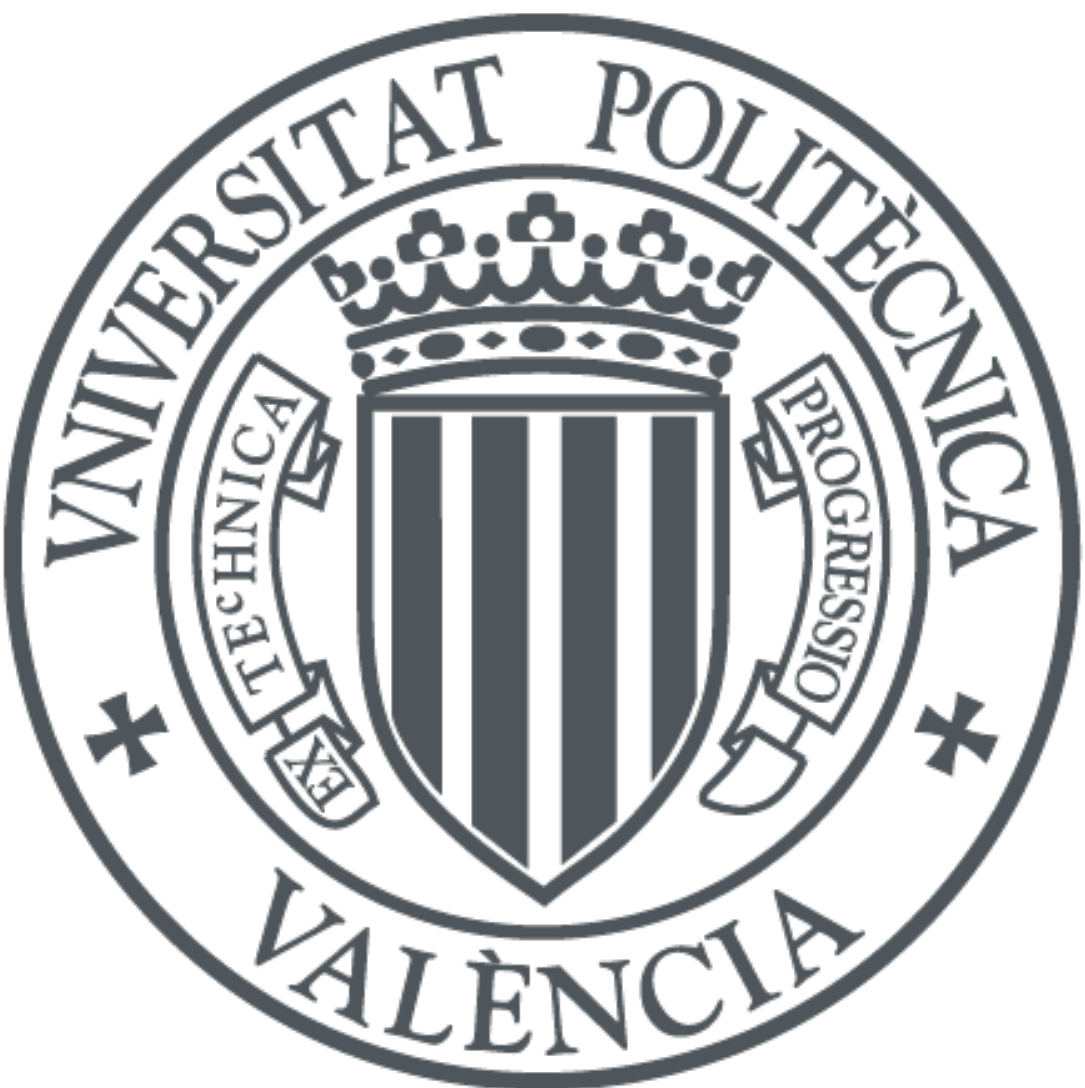

The final publication is available at

https://doi.org/10.1002/asia.201700031

Copyright John Wiley \& Sons

Additional Information 


\title{
Acetylcholinesterase-capped mesoporous silica nanoparticles controlled by presence of inhibitors.
}

\author{
Lluís Pascual ${ }_{,}^{[a, b, c]}$ Sameh El Sayed, ${ }^{[a, b, c]}$ María D. Marcos, ${ }^{[a, b, c]}$ Ramón Martínez-Máñez ${ }^{*[a, b, c]}$ and Félix \\ Sancenón ${ }^{[a, b, c]}$
}

\begin{abstract}
Two different acetylcholinesterase (AChE)-capped mesoporous silica nanoparticles (MSNs), S1-AChE and S2-AChE, were prepared and characterized. MSNs were loaded with rhodamine $\mathrm{B}$ and the external surface was functionalized with either pyridostigmine derivative $\mathbf{P 1}$ (to yield solid $\mathbf{S 1}$ ) or neostigmine derivative P2 (to obtain S2). The final capped materials were obtained by coordinating grafted $\mathbf{P} 1$ or $\mathbf{P} 2$ with AChE's active sites (to give S1-AChE and S2-AChE, respectively). Both materials were able to release rhodamine $B$ in the presence of diisopropylfluorophosphate (DFP) or neostigmine in a concentrationdependent manner via the competitive displacement of $\mathrm{AChE}$ through DFP and neostigmine coordination with the AChE's active sites. The responses of S1-AChE and S2-AChE were also tested with other enzyme inhibitors and substrates. These studies suggest that S1-AChE nanoparticles can be used for the selective detection of nerve agent simulant DFP and paraoxon.
\end{abstract}

\section{Introduction}

In the last few decades, nanotechnology has provided numerous examples of abiotic devices capable of performing certain operations in response to minor changes in the environment in which the nanomaterial is located. One appealing concept inside the realm of these "smart nanodevices" is the design of controlled release nanoparticles that contain "molecular gates" ${ }^{[1]}$ These gated nanodevices are usually formed by three subunits; i.e., (i) a suitable inorganic porous scaffold; (ii) a payload that is loaded onto the porous network; and (iii) a molecular or supramolecular capping ensemble, grafted onto the outer surface of the support, which allows cargo release upon the application of an external stimulus (e.g., light, $\mathrm{pH}$, temperature, magnetic fields, presence of certain (bio)chemical species, etc.). ${ }^{[2-5]}$

One of the supports that has been extensively used to prepare gated materials is mesoporous silica nanoparticles (MSNs) owing to some of their properties, such as relatively well-known functionalization chemistry (using trialkoxysilane

[a] LI. Pascual, Dr. S. El Sayed, Dr. M. D. Marcos, Prof. R. MartínezMáñez, Dr. F. Sancenón

Departamento de Química, Universidad Politécnica de Valencia Camino de Vera s/n, 46022, Valencia, Spain E-mail:rmaez@qim.upv.es

[b] LI. Pascual, Dr. S. El Sayed, Dr. M. D. Marcos, Prof. R. Martínez Máñez, Dr. F. Sancenón

Instituto Interuniversitario de Investigación de Reconocimiento Molecular y Desarrollo Tecnológico (IDM), Universitat Politécnica de Valencia, Universitat de Valencia.

[c] LI. Pascual, Dr. S. El Sayed, Dr. M. D. Marcos, Prof. R. MartínezMáñez, Dr. F. Sancenón

CIBER de Bioingeniería, Biomateriales y Nanomedicina (CIBER$\mathrm{BBN})$

Supporting Information of this article can be found under http://dx.doi.org/10.1002/asia derivatives), high stability and presence of finely-tuned pores within the nanometric range (typically $2-3 \mathrm{~nm}$ ). ${ }^{[6]}$ While dealing with the payload, a myriad of chemical and biochemical molecules, e.g., drugs, biomolecules, redox active species and dyes/fluorophores, has been encapsulated onto MSNs-based supports. $^{[7-11]}$

These gated materials have found notable applications in controlled releases in the biotechnological and biomedical fields, ${ }^{[12]}$ especially in the drug delivery area for the potential treatment of different diseases. ${ }^{[13,14]}$ Gated materials have also been applied in sensing and recognition protocols. ${ }^{[15]}$ For the latter application, the underlying idea is that the coordination or a reaction of a certain analyte with the capping unit can modulate the delivery of a previously stored reporter, usually a dye or fluorophore, from the pores to the solution, which gives rise to a simple-to-detect chromo-fluorogenic signal.

Form another point of view, the implementation of enzymes in gated materials has attracted much attention in recent years. For instance, enzymes can be used as triggers to induce the chemical degradation of certain biomolecules used as gates to allow cargo release. ${ }^{[16-18]}$ In this scenario, several examples of gated materials capable of delivering an entrapped payload in the presence of esterases, amidases, azoreductases, glycosidases and other enzymes have been reported. ${ }^{[19-23]}$ These materials can potentially find applications in personalized biomedicine by taking advantage of the overexpression of certain enzymes in target diseases, which triggers pore opening and cargo release in only target tissues or organs. ${ }^{[24]}$

Enzymes have also been used recently as capping subunits. In this specific use of enzymes, Martínez-Máñez and co-workers used cyclodextrin-modified glucose oxidase to close the pores of mesoporous silica nanoparticles, loaded with a dye and functionalized with a benzimidazole derivative, through the formation of benzimidazole-cyclodextrin inclusion supramolecular complexes. ${ }^{[25]}$ In the presence of glucose, the capping enzyme produced gluconic acid that induced benzimidazole protonation, dethreading of the supramolecular complex and dye release. In a second example, Lu and coworkers grafted glucosamine derivatives onto the external surface of mesoporous silica nanoparticles. Then pores were capped with glucose oxidase through the coordination of glucosamine with the enzyme's active site. In the presence of glucose, marked delivery of an entrapped dye was observed due to preferential glucose binding with the glucose oxidase active site and subsequent enzyme displacement from the surface. ${ }^{[26]}$ Along this line, Villalonga and co-workers prepared mesoporous silica nanoparticles loaded with a dye and the external surface was functionalized with a boronic acid derivative. The capped material was obtained upon the addition of lactosefunctionalized esterase through the formation of boronate esters between disaccharides and the grafted boronic acids. ${ }^{[27]}$ The entrapped dye was released in the presence of glucose or ethyl 
butyrate. Ren et al also used glucose oxidase as caps, in which case the opening protocol was related with the hydrolysis of the enzyme by a protease. ${ }^{[28]}$ Very recently, Bein and co-workers prepared mesoporous silica nanoparticle loaded with fluorescein and capped with carbonic anhydrase (which binds reversibly through its active center to aryl sulfonamide groups grafted onto the nanoparticles surface). ${ }^{[29]}$ These nanoparticles delivered its cargo at $\mathrm{pH} 5.5$ due to sulfonamide protonation with the subsequent detachment of the capping enzyme. On the other hand, other hybrid materials containing enzymes (adsorbed ${ }^{[30]}$ or grafted $^{[31]}$ ) onto the external surface of the inorganic scaffolds have been described. In these examples, enzymes are not used properly as capping agents but as a functional part of the gating mechanism.

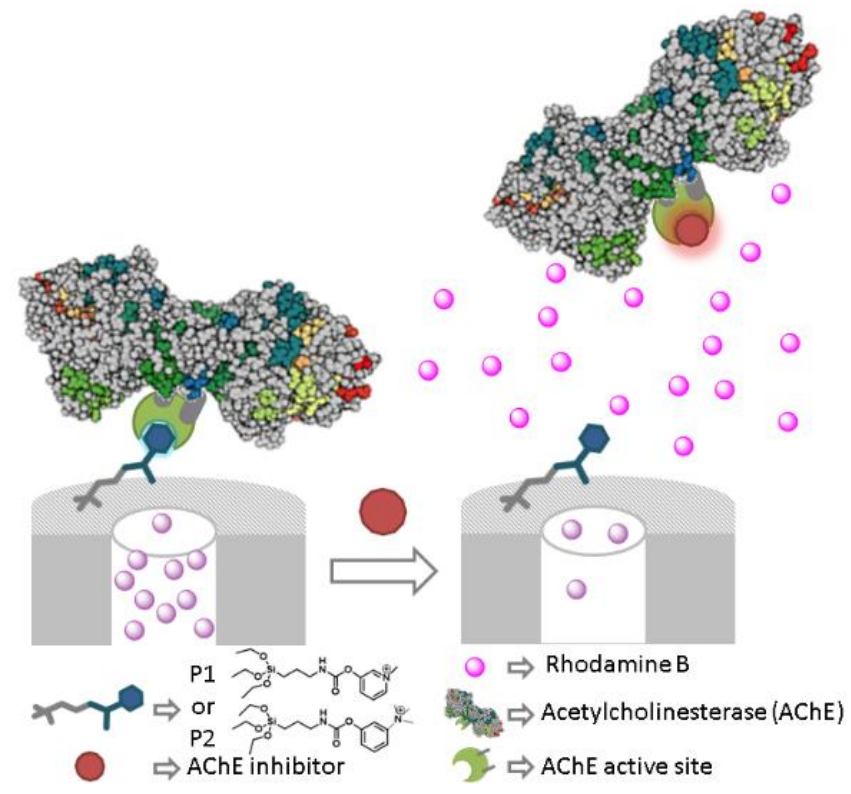

Scheme 1. Schematic representation of the opening mechanism of solid S1AChE (grafted with P1) and solid S2-AChE (grafted with P2).

After taking into account the above-mentioned facts and our interest in developing gated nanomaterials for applications in controlled delivery and recognition/sensing protocols, ${ }^{[32]}$ we report herein the use of acetylcholinesterase (AChE) as a cap for the development of nanodevices that are expected to release their cargo in the presence of AChE inhibitors. For this purpose, we selected silica mesoporous nanoparticles as the inorganic scaffold and loaded pores with rhodamine B. In a second step, the external surface of the loaded nanoparticles was functionalized with two different derivatives of reversible AChE inhibitors; i.e. pyridostigmine and neostigmine (P1 and P2 in Scheme 1). Finally, addition of AChE induced pore capping by coordinating P1 and P2 with the enzyme's active sites (to obtain S1-AChE and S2-AChE, respectively). The AChE-capped solids were expected to show "zero release", but would deliver the cargo in the presence of other inhibitors with more affinity to the AChE enzyme (see Scheme 1). We selected the AChE enzyme because this is a well-studied enzyme whose inhibitors (i.e. chemical warfare agents, neuroactive drugs or pesticides) are substances of interest. In fact capped solids S1-AChE and S2AChE can be potentially used as probes for the selective detection of diisopropylfluorophosphate (DFP) or paraoxon, (vide infra). A preliminary communication related with the performance of solid S1-AChE has been recently published by us. ${ }^{[33]}$

\section{Results and Discussion}

Synthesis of gated nanoparticles. Two different gated materials, S1-AChE and S2-AChE, were prepared using MSNs as the inorganic scaffold.

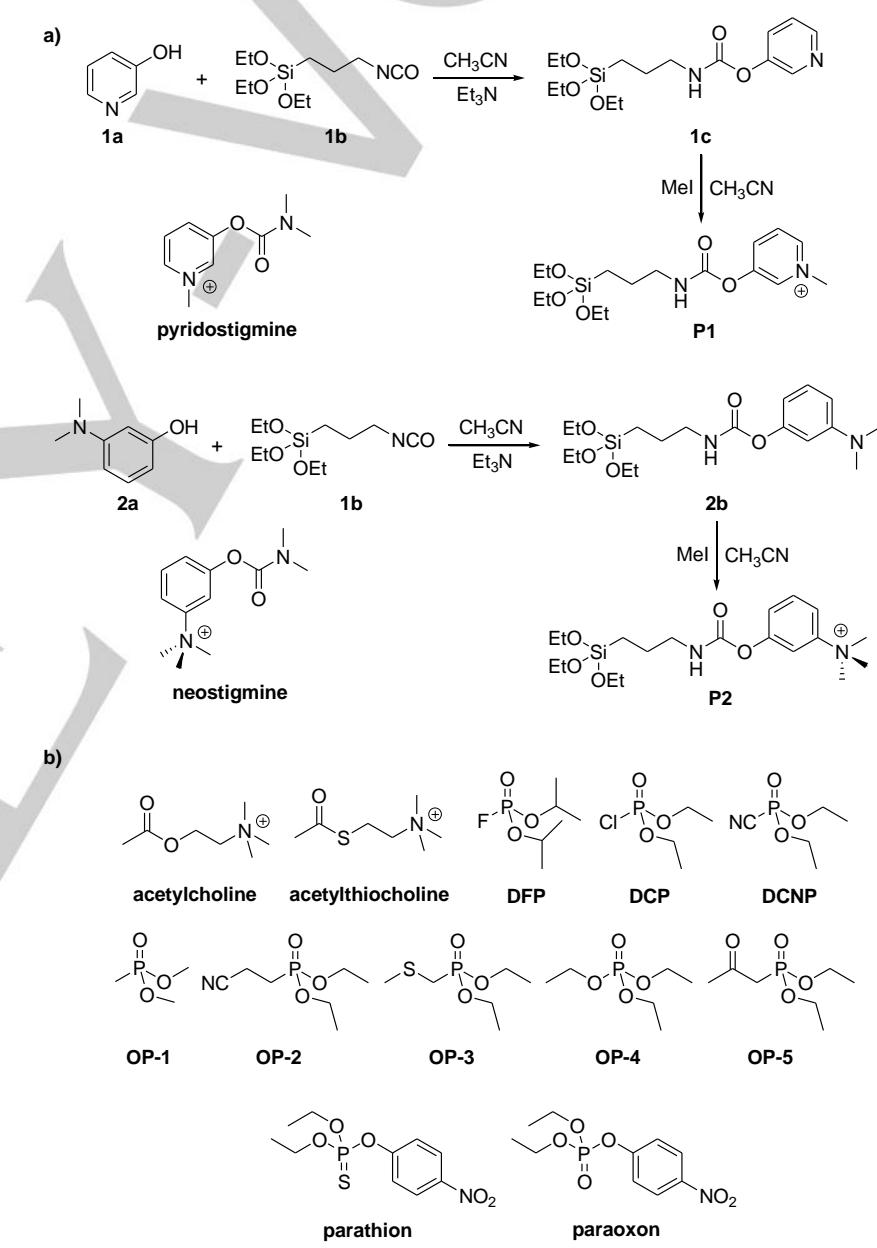

Scheme 2. a) The synthetic protocols used to prepare the $\mathbf{P} \mathbf{1}$ and $\mathbf{P} 2$ derivatives and the chemical structures of pyridostigmine and neostigmine. $b$ ) The chemical structures of the substrates and inhibitors used herein with solids S1-AChE and S2-AChE.

MSNs were synthesized in alkaline media following wellknown procedures that use $n$-cetyltrimethylammonium bromide $(C T A B)$ as the directing agent for the condensation of inorganic precursor tetraethylorthosilicate (TEOS). ${ }^{[34]}$ The obtained powder 
was washed and the surfactant was subsequently removed by calcination. Then the pores of MSNs were loaded with fluorophore rhodamine $B$ by stirring a suspension of nanoparticles in a concentrated acetonitrile solution of the dye (solid S0). Afterward P1 and P2 were grafted onto the external surface of the loaded nanoparticles, which yielded solids S1 and S2. Final gated nanoparticles S1-AChE and S2-AChE were prepared by suspending $\mathbf{S} 1$ and $\mathbf{S} 2$ in an aqueous (TRIS pH 8.0) solution of AChE for $30 \mathrm{~min}$. In this step, AChE was immobilized onto the external surface of the nanoparticles through the reversible interaction of the enzyme's active site with the grafted $\mathbf{P 1}$ and $\mathbf{P} 2$ inhibitors with subsequent pore capping.

$\mathbf{P 1}$ is a derivative of pyridostigmine and was prepared by a two-step procedure. In the first step, 3-hydroxypyridine (1a) was reacted with (3-isocyanatopropyl)triethoxysilane (1b), which yielded carbamate derivative 1c. In a second step, the nitrogen atom of the pyridine moiety in 1c was quaternized with methyliodide to yield P1 (see Scheme 2). A similar two-step synthetic protocol was used for the preparation of $\mathbf{P 2}$, which is a derivative of neostigmine, another reversible inhibitor of AChE. In this case, 3-(dimethylamino)phenol (2a) was reacted with (3isocyanatopropyl)triethoxysilane (1) to yield carbamate $\mathbf{2 b}$. Compound $\mathbf{P} \mathbf{2}$ was obtained after reacting $\mathbf{2 b}$ with methyl iodide (see Scheme 2).

Materials characterization. MSNs and solids S1 and S2 were characterized by powder X-ray diffraction (PXRD), transmission electron microscopy (TEM), $\mathrm{N}_{2}$ adsorption-desorption isotherms, thermogravimetric measurements and elemental analyses.

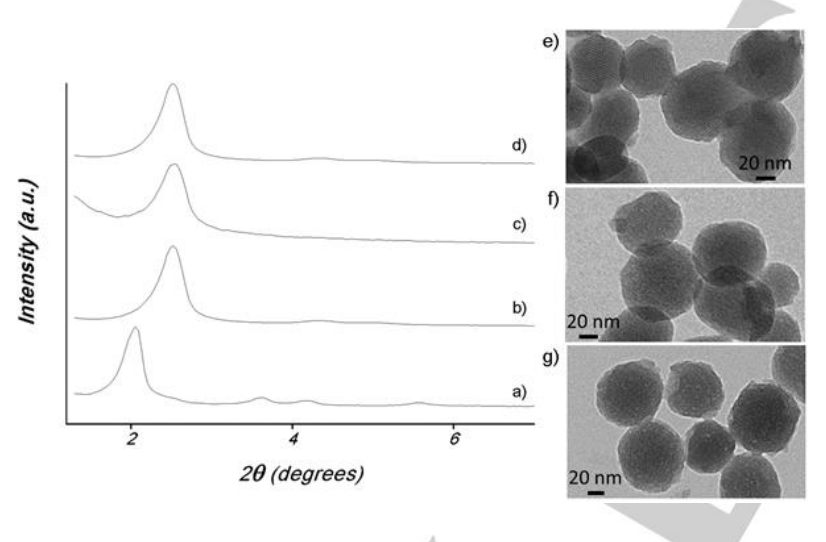

Figure 1. Left: The powder X-ray patterns of (a) as-made MSNs, (b) calcined MSNs, (c) solid S1, (d) solid S2. Right: The TEM images of (e) calcined MSNs, (f) solid S1; (g) solid S2

Table 1. The BET-specific surface values, pore volumes, and pore sizes calculated from the $\mathrm{N}_{2}$ adsorption-desorption isotherms.

\begin{tabular}{lccc}
\hline Solid & $\begin{array}{c}\mathrm{S}_{\mathrm{BET}} \\
{\left[\mathrm{m}^{2} \mathrm{~g}^{-1}\right]}\end{array}$ & $\begin{array}{c}\text { BJH Pore size } \\
{[\mathrm{nm}]}\end{array}$ & $\begin{array}{c}\text { Total Pore Volume } \\
{[\mathrm{b}]} \\
{\left[\mathrm{cm}^{3} \mathrm{~g}^{-1}\right]}\end{array}$ \\
\hline MCM-41 & 747.5 & 2.45 & 0.33 \\
S1 & 65.9 & - & 0.03 \\
S2 & 137 & - & 0.10 \\
\hline
\end{tabular}

$[a, b]$ Pore volumes and pore sizes were associated with only intraparticle mesopores.
Figure 1 shows the PXRD patterns of MSNs as made (1a), the calcined MSNs (1b) and solids S1 (1c) and S2 (1d). The PXRD of the as-made MSNs showed four low-angle peaks, typical of a hexagonal-ordered array of pores that can be indexed as (100), (110), (200) and (210) Bragg reflections. A shift of the (100) peak and a remarkable broadening of the other reflections in the calcined MSNs was observed and ascribed to the further condensation of the silanol groups in the calcination step. For solids S1 and S2, the reflection (100) remained and indicated that the mesoporous structure was preserved in these solids despite filling pores with rhodamine $B$ and anchoring the P1 and P2 functionalities on the nanoparticles' surface. Figure 1 shows the representative TEM images of the calcined MSNs (1e) and solids S1 (1f) and S2 (1g). Here it can be seen that S1 and S2 preserve the spherical shape of the calcined nanoparticles, and have a similar average diameter of ca. $100 \pm$ $8 \mathrm{~nm}$. In addition, the typical porosity associated with this type of inorganic support can be observed in the three materials.

$\mathrm{N}_{2}$ adsorption-desorption studies were also carried out of the calcined MSNs and of both S1 and S2 (see Figure 2). The calcined MSNs showed a typical type IV curve, which is characteristic of this mesoporous support. The curve reveals the typical adsorption step at intermediate $\mathrm{P} / \mathrm{P}_{0}$ values $(0.1-0.3)$ in relation to the nitrogen condensation inside mesopores. The pore diameter distribution (PSD) of this sample was calculated by the Barret-Joyner-Halenda (BJH) method. A narrow BJH pore distribution and the absence of a hysteresis loop within this interval suggest the existence of uniform cylindrical mesopores (pore diameter of $2.45 \mathrm{~nm}$ and pore volume of $0.33 \mathrm{~cm}^{3} \mathrm{~g}^{-1}$, calculated on the adsorption branch of the isotherm). The application of the Brunauer-Emmett-Teller (BET) model gave a value of $747.5 \mathrm{~m}^{2} \mathrm{~g}^{-1}$ for the total specific surface. As could be seen in Table 1, the surface area and pore volume of solid $\mathbf{S 1}$ are smaller than that of $\mathbf{S 2}$. Taking into account the fact that experimental procedure used to prepare both solids is the same, the differences in surface area and pore volume measured could be ascribed to the different chemical structures of the grafted inhibitors P1 and P2. At this respect, both inhibitors are of similar sizes and have a positive charge. The main difference arises from the fact that in $\mathbf{P 1}$ the positive charge is located in a nitrogen atom of a pyridine heterocycle whereas in $\mathbf{P 2}$ is located in a nitrogen atom directly linked to a benzene ring. The more planar P1 structure could induce the formation of a denser monolayer in the outer surface of $\mathbf{S 1}$ than that obtained in $\mathbf{S 2}$ upon $\mathbf{P 2}$ grafting. The formation of different monolayers was reflected in the quantities of $\mathbf{P} \mathbf{1}$ and $\mathbf{P} \mathbf{2}$ grafted $\left(0.93 \mathrm{mmol} \mathrm{g}^{-1}\right.$ $\mathrm{SiO}_{2}$ for $\mathbf{S} 1$ and $0.48 \mathrm{mmol} \mathrm{g}^{-1} \mathrm{SiO}_{2}$ for S2) in the outer surface of both solids. Taking into account these values, the steric crowding around the pores of $\mathbf{S 1}$ is higher than that of S2. As a consequence, the leaching of rhodamine $B$ from the inner of the pores in $\mathbf{S 1}$ is more disabled when compared to that in $\mathbf{S 2}$. Taking into account these facts, the filling of the pores in $\mathbf{S 1}$ is a little bit more efficient that in $\mathbf{S 2}$ and, as a consequence, the surface area and pore volumes measured are smaller. 


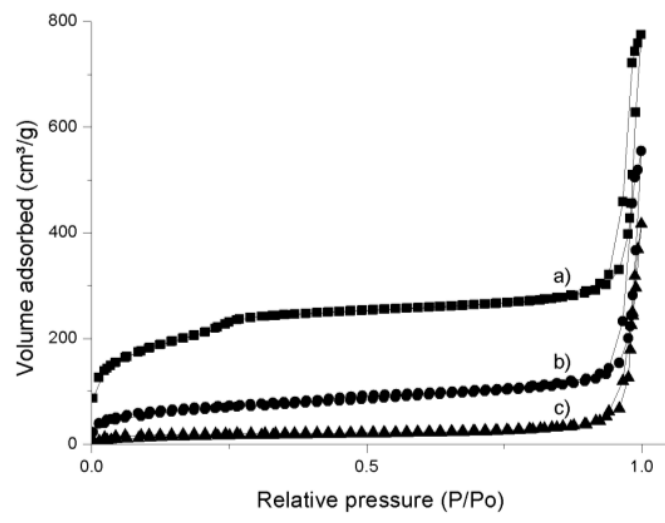

Figure 2. The $\mathrm{N}_{2}$ adsorption-desorption isotherms for (a) the calcined MCM-41 nanoparticles, (b) $\mathbf{S} 2$ and (c) $\mathbf{S} 1$.

The $\mathrm{N}_{2}$ adsorption-desorption isotherms of solids $\mathbf{S} 1$ and S2 are typical of mesoporous systems with filled mesopores, and both the adsorbed $\mathrm{N}_{2}$ volume and the specific surface area drastically dropped (see Table 1). This reduction in the BET surface, compared with that of the MCM-41 starting material, was ascribed to loading pores with rhodamine $B$ and to functionalizing the surface with $\mathbf{P 1}$ and $\mathbf{P 2}$.

Finally, the organic matter content of both rhodamine $\mathrm{B}$ and $\mathbf{P 1 / P 2}$ in nanoparticles $\mathbf{S} 1$ and $\mathbf{S} 2$ was determined by combining thermogravimetric and elemental analysis data. The results are summarized in Table 2 .

Table 2 The content $(\alpha)$ of the anchored molecules and dye in $\mathrm{mmol} \mathrm{g}^{-1}$ of $\mathrm{SiO}_{2}$

\begin{tabular}{lccc}
\hline Solid & $\begin{array}{c}\alpha_{\text {Inhibitor derivative }} \\
\left(\mathrm{mmol} \mathrm{g}^{-1} \mathrm{SiO}_{2}\right)\end{array}$ & $\begin{array}{c}\alpha_{\text {rhodamine B }} \\
\left(\mathrm{mmol} \mathrm{g}^{-1} \mathrm{SiO}_{2}\right)\end{array}$ & $\begin{array}{c}\alpha_{\text {Organic matter }} \\
(\% \mathrm{~g} / \mathrm{g})\end{array}$ \\
\hline S1 & 0.93 & 0.012 & 25.1 \\
S2 & 0.48 & 0.034 & 17.6
\end{tabular}

The final solids, S1-AChE and S2-AChE were prepared by suspending $\mathbf{S} 1$ or $\mathbf{S} 2$ in an aqueous solution of AChE (TRIS buffer at $\mathrm{pH}$ 8.0) for $30 \mathrm{~min}$ (see the Experimental section for further details). Both final capped nanoparticles were prepared in small quantities and, for this reason, it was not possible to carry out a complete characterization of the solids. However, the UV-visible studies of the solution before and after the capping process allowed us to estimate that amounts of $250 \pm 40$ and $200 \pm 20 \mu$ mols g $^{-1}$ AChE attached in S1-AChE and S2-AChE, respectively.

The capping process and enzyme immobilization were also followed by measuring AChE activity using Ellman's assay (see Figure 3 and the Experimental section for details) before and after attaching AChE onto the external surface of the solids. Before grafting, AChE activity was $106.41 \mathrm{U} \mathrm{mg}^{-1}$, whereas this activity dropped to $1.97 \mathrm{U} \mathrm{mg}^{-1}$ and $2.89 \mathrm{U} \mathrm{mg}^{-1}$ for S1-AChE and S2-AChE, respectively, after immobilization. This reduction in enzyme activity was attributed to AChE immobilization on the surface by the interaction of the enzyme's active sites with the grafted inhibitors. The detected low residual enzyme activity was tentatively ascribed to either (i) the small amounts of enzyme adsorbed physically onto the external surface of MSNs and/or (ii) presence of two active sites in AChE, which were perhaps not both blocked by the inhibitors.

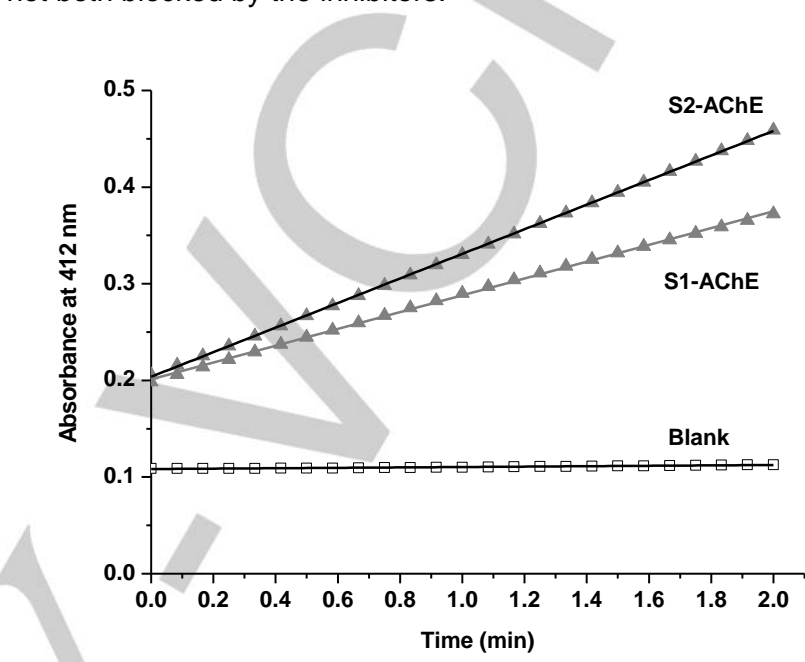

Figure 3. Absorbance at $412 \mathrm{~nm}$ which corresponds to the $\mathrm{TNB}^{2-}$ formed in the Ellman's assay for the AChE activity measurement in nanoparticles S1AChE and S2-AChE

Dye delivery studies in the presence of $\mathrm{AChE}$ inhibitors: As stated above, the presence of inhibitors with more affinity to ACHE than $\mathbf{P} \mathbf{1}$ or $\mathbf{P 2}$ was expected to induce a displacement of the enzyme from the nanoparticles, with the subsequent rhodamine $B$ release. In a first step, uncapping studies were carried out with diisopropylfluorophosphate (DFP) and neostigmine. DFP is a quasi-irreversible AChE inhibitor commonly used as a nerve agent mimic, while neostigmine is a reversible AChE inhibitor used to treat myasthenia gravis. The main differences between DFP and neostigmine, in relation to their interaction with AChE, are associated with both the different coordination ability to the enzyme and the inhibition mechanism. In line with this, the half maximal inhibitory concentration $\left(\mathrm{IC}_{50}\right)$ of DFP is $120 \mathrm{nM},{ }^{[35]}$ whereas the value for neostigmine is $2 \mathrm{nM}$. These values reflected the better affinity of neostigmine, compared with DFP, to the AChE active sites. Moreover, organophosphate-based inhibitors, such as DFP, tend to covalently attach to the serine residue of the enzyme active site to form a very stable complex that can remain unaltered for hours or even days. When dealing with carbamatebased inhibitors, e.g., neostigmine, their mode of interaction with $\mathrm{AChE}$ is similar to that of acetylcholine, but with slower kinetics (i.e., hydrolysis will take from minutes to hours). ${ }^{[36]}$

In a typical experiment, $750 \mu \mathrm{g}$ of S1-AChE were suspended in TRIS buffer ( $\mathrm{pH} 8.0$ ) and the resulting suspension was divided into three equal fractions. Two fractions were diluted with TRIS buffer, and DFP or neostigmine was added (a final DFP and neostigmine concentration of $10 \mathrm{mM}$ ). The other 
fraction, which acted as a blank, was filled with MilliQ water. The same procedure was repeated for the S2-AChE nanoparticles. All the suspensions were stirred at room temperature, aliquots were extracted at the scheduled times and the solid was removed by centrifugation. Dye delivery to the bulk solution was easily detected by monitoring the emission band of rhodamine $B$ in the solution at $572 \mathrm{~nm}$ upon excitation at $555 \mathrm{~nm}$. The obtained cargo release profiles are shown in Figure 4. Table 3 summarizes the $\mathrm{IC}_{50}$ values for some inhibitors used in this work.
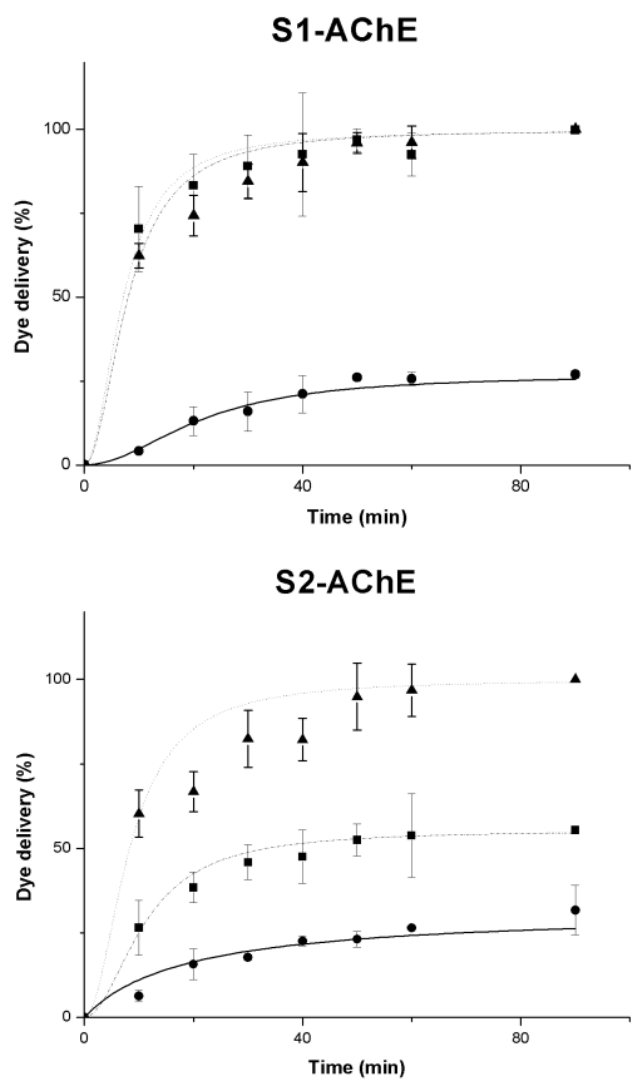

Figure 4. Kinetics of the release of rhodamine B from solids S1-AChE and S2AChE in the absence ( blank) and presence of DFP $(\boldsymbol{\theta})$ and neostigmine $(\mathbf{\Delta})$.

As seen in Figure 4, in the absence of DFP or neostigmine, a poor rhodamine $\mathrm{B}$ release from solid S1-AchE occurred (less than $5 \%$ of the maximum dye delivered after 5 min and ca. $20 \%$ after $90 \mathrm{~min}$ ). This partial dye delivery observed in the absence of DFP and neostigmine was ascribed to the fact that P1 (as a pyridostigmine) is a reversible inhibitor of the AChE enzyme. As a result, a slow enzymatic hydrolysis of $\mathbf{P 1}$ may happen with time, and the subsequent detachment of AChE from the solid surface and rhodamine $B$ release can occur. However, when DFP or neostigmine was present, a remarkable rhodamine B release was observed (ca. $80 \%$ of the maximum dye delivered after $10 \mathrm{~min}$ ). The release of the rhodamine $B$ entrapped inside the pores of solid S1-AChE was attributed to a preferential coordination of DFP and neostigmine with the active sites of the AChE enzyme; i.e., both the used inhibitors $\left(\mathrm{IC}_{50}\right.$ of 120 and 2 $\mathrm{nM}$ for DFP and neostigmine, respectively) displayed stronger interactions with AChE than that shown by pyridostigmine derivative $\mathbf{P 1}$ (the $\mathrm{IC}_{50}$ for pyridostigmine was $330 \mathrm{nM}$ ).

The release profile in the hybrid materials that used enzymes as caps via the interaction of the active site with the anchored inhibitors can be easily modulated by changing the chemical nature of the anchored inhibitor. This was clearly seen when the behavior of S1-AChE in the presence of DFP and neostigmine was compared with that of S2-AChE. For the latter (functionalized with P2, a neostigmine derivative), the cargo delivery profiles in the presence of DFP and neostigmine are shown in Figure 4. In the absence of DFP or neostigmine, a certain, yet poor, rhodamine $B$ release was observed, which was also tentatively ascribed to a slow enzymatic hydrolysis of the P2 derivative. In contrast, the kinetic profiles obtained in the presence of DFP or neostigmine clearly differed. As seen in Figure 4, DFP was unable to induce a marked AChE displacement from S2-AChE and only $40 \%$ of the maximum rhodamine $B$ release was observed after 20 min. However when neostigmine was used, nearly $90 \%$ of the dye was delivered in the same time. This different behavior was ascribed to the interaction ability of DFP and nesotigmine with AChE compared to that of the grafted P2. In fact, addition of DFP induced a moderate displacement of AChE because its $I_{50}$ value was higher than that of $\mathbf{P 2}$ and it was unable to completely detach AChE from the nanoparticles' surface. Neostigmine had a similar $\mathrm{IC}_{50}$ to that of $\mathbf{P 2}$ and, for this reason, was able to compete for coordination with the enzyme active sites with the subsequent pore opening.

Table 3. The $\mathrm{IC}_{50}$ values from the bibliography of the most relevant $\mathrm{AChE}$ inhibitors tested or grafted on solids. ${ }^{[35,37-40]}$

\begin{tabular}{cc}
\hline Compound & $\mathrm{IC}_{50}(\mathrm{nM})$ \\
\hline Pyridostigmine (P1 precursor) & 330 \\
Neostigmine (P2 precursor) & 2 \\
DFP & 120 \\
Pox & 130 \\
Pthion & 12590 \\
\hline
\end{tabular}

The rhodamine $B$ release from nanoparticles S1-AChE and S2-AChE in the absence and presence of inhibitors was tested at $\mathrm{pH} 8.0$ because this is the optimal proton concentration for the AChE enzyme. However, the rhodamine $B$ release from solid S1-AChE in the presence and absence of DFP at $\mathrm{pH} 6.0$ and 4.0 was also tested following a similar procedure to that described above. Solid S1-AChE was selected for this study because $\mathbf{P 1}$ has the higher $\mathrm{IC}_{50}$ value and the $\mathrm{AChE}$ enzyme is less effectively retained compared to solid S2-AChE. This weaker coordination of AChE to P1 could be disrupted more easily by changes in the environment, e.g., changes in the proton concentration. Moreover, DFP was selected for its weaker interaction with AChE compared with neostigmine. The 
cargo release profiles at $\mathrm{pH} 4.0,6.0$ and 8.0 are shown in Figure 5. As we can see in the figure, the delivery profiles at $\mathrm{pH} 4.0,6.0$ and 8.0 are similar. The most remarkable difference at $\mathrm{pH} 4.0$ and 6.0 was an enhanced pore closure in the absence of DFP. This reduction in rhodamine $B$ leakage was tentatively ascribed to the lower AChE enzymatic activity at an acidic $\mathrm{pH}$. Consequently, the hydrolysis rate of $\mathbf{P 1}$ also lowered and the cargo delivery from S1-AChE decreased.

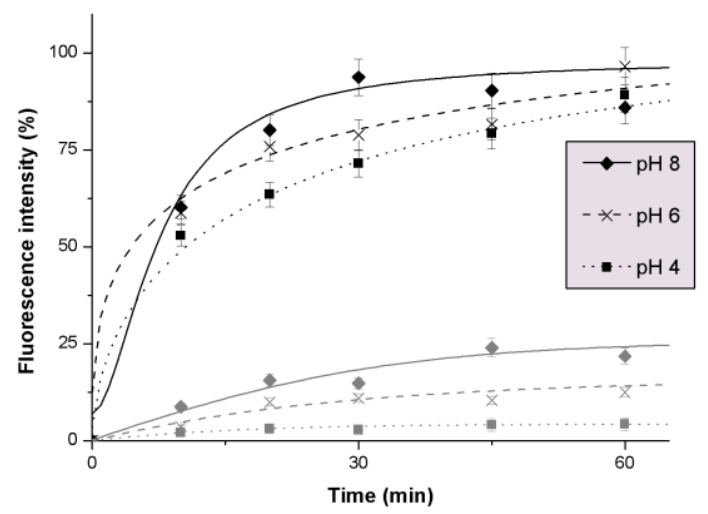

Figure 5. The rhodamine B release profiles from solid S1-AChE in the absence and in the presence of DFP at three different $\mathrm{pHs}$. The DFP response is drawn in black: $\mathrm{pH} 8(\diamond), 6(\mathrm{X})$ and $\mathrm{pH} 4(\boldsymbol{\square})$ while blanks are drawn in gray: $\mathrm{pH} 8(\diamond), 6(X)$ and $\mathrm{pH} 4(\square)$.

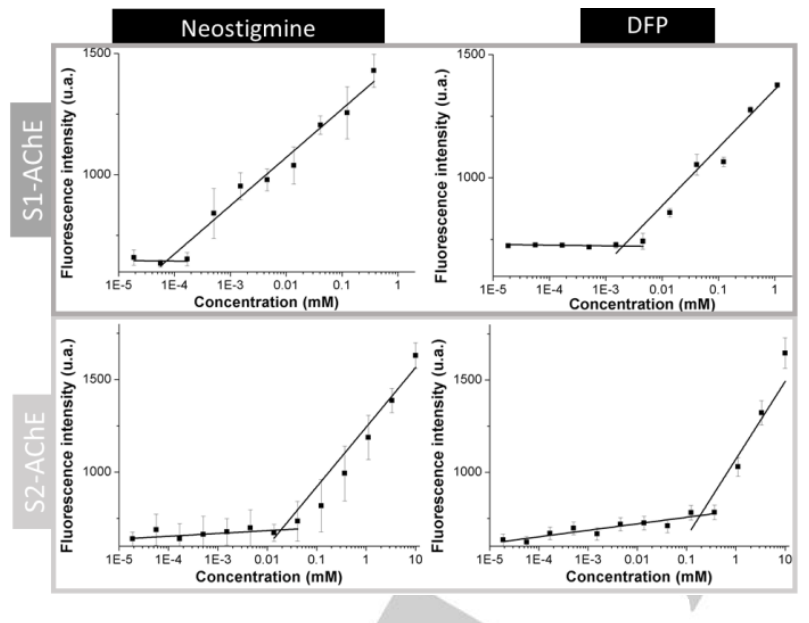

Figure 6. Emission intensity at $572 \mathrm{~nm}$ (excitation at $555 \mathrm{~nm}$ ) of the rhodamine B release from solids S1-AChE and S2-AChE in the presence of increasing amounts of neostigmine and DFP (measured 15 min after addition).

After assessing the cargo delivery behavior of nanoparticles S1-AChE and S2-AChE with DFP and neostigmine, studies of the payload delivery in the presence of increasing amounts of both inhibitors were carried out. The underlying idea was to assess the minimum quantity of DFP or neostigmine that induced pore opening and rhodamine $B$ release. The corresponding titration profiles obtained for both solids with DFP and neostigmine are shown in Figure 6. From these graphics, the limit of detections (LOD) to detect DFP and neostigmine were calculated and are included in Table 4.

Table 4. Minimal neostigmine and DFP concentrations that induced the pore opening of nanoparticles S1-AChE and S2-AChE

\begin{tabular}{ccc}
\hline Solid & Neostigmine $(\mu \mathrm{M})$ & DFP_ $(\mu \mathrm{M})$ \\
\hline S1-AChE & 0.11 & 3 \\
S2-AChE & 20 & 200 \\
\hline
\end{tabular}

From the profiles shown in Figure 6 and from the values of Table 4, the LOD for neostigmine and DFP in both solids clearly related with the affinity of neostigmine and DFP to coordinate with AChE. When dealing with nanoparticles S1-AChE, the affinity of $\mathbf{P 1}$ to AChE was relatively weak and could be easily disrupted upon the addition of DFP and neostigmine. Moreover, neostigimine has a stronger affinity to AChE $\left(\mathrm{IC}_{50}\right.$ of $\left.2 \mathrm{nM}\right)$ than DFP (an IC ${ }_{50}$ of $120 \mathrm{nM}$ ) and, consequently, a smaller amount of the former was needed to induce rhodamine $B$ release. With neostigmine, a concentration as low as $110 \mathrm{nM}$ was able to displace AChE from the surface of S1-AChE, whereas rhodamine $B$ release was not seen for DFP until a $3 \mu \mathrm{M}$ concentration was reached. A similar trend was observed with solid S2-AChE, but in this case the amount of neostigmine and DFP that induced pore opening was bigger (compared with solid S1-AChE) due to the stronger affinity of P2 to AChE compared with P1. The LOD for neostigmine and DFP using S2-AChE were $20 \mu \mathrm{M}$ and $200 \mu \mathrm{M}$, respectively. Besides, the LOD measured for DFP and neostigmine using S1-AChE and S2AChE nanoparticles are similar to those obtained for other sensory systems described in the literature (see Supporting Information).

The above-indicated studies clearly demonstrated that AChE displacement, and pore opening, from the surface of S1AChE and S2-AChE were the result of competition between the grafted (P1 and $\mathbf{P 2}$ ) and free inhibitors (neostigmine and DFP) to coordinate with the enzyme's active sites.

Selectivity studies of nanoparticles S1-AChE and S2-AChE: After assessing the opening behavior of S1-AChE and S2-AChE in the absence and presence of neostigmine and DFP, we paid attention to study the response of both solids in the presence of other chemical species. For this study we selected the following as potential AChE inhibitors and substrates; neostisgmine (NG), pyridostigmine $(\mathrm{PG})$, acetylcholine $(\mathrm{ACh})$, acetylthiocholine (ASCh), diisopropylfluorophosphate

(DFP), diethylchlorophosphate (DCP), diethylcyanophosphonate (DCNP), parathion (Pthion), paraoxon (Pox), dimethylmethyl phosphonate (OP-1), diethyl (2-cyanoethyl)phosphonate (OP-2), diethyl (methylthiomethyl) phosphonate (OP-3), dimethyl chlorothiophosphate (OP-4) and ethyl dichlorophosphate (OP-5). Neostigmine and pyridostigmine are potent inhibitors of AChE, whereas $\mathrm{ACh}$ and $\mathrm{ASCh}$ are the natural substrates of the enzyme. DFP, DCP and DCNP are nerve agent simulants ${ }^{[41]}$ and OP1-OP5 are a family of organophosphates and phosphonates. 
Finally, parathion is a commonly used pesticide and paraoxon is its degradation product. ${ }^{[42]}$

In a typical experiment, the release of rhodamine $B$ from nanoparticles S1-AChE and S2-AChE in the presence of these chemicals at the $5 \mathrm{mM}$ concentration and after $15 \mathrm{~min}$ in TRIS buffer at $\mathrm{pH} 8.0$ was tested. The obtained results are shown in Figure 7.

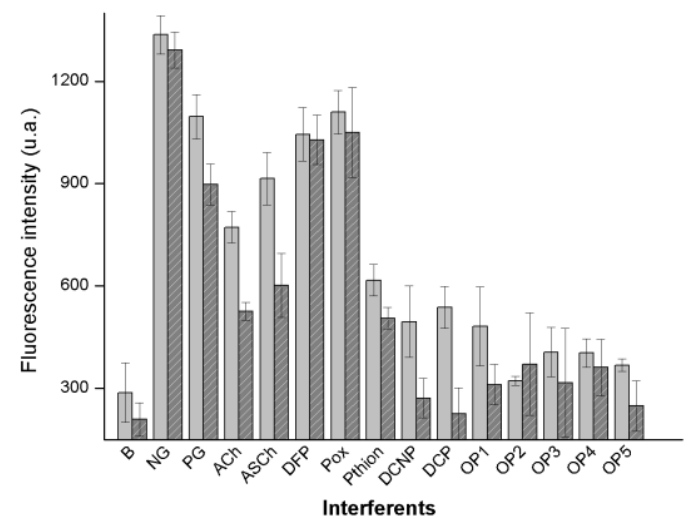

Figure 7. Emission intensity of rhodamine $B$ at $572 \mathrm{~nm}$ (excitation at $555 \mathrm{~nm}$ ) released from solid S1-AChE (dark gray bars) or S2-AChE (light gray bars) (TRIS $100 \mathrm{mM}, \mathrm{pH}$ 8.0) in the presence of the substrates, inhibitors and potential interfering agents of $\mathrm{AChE}(5 \mathrm{mM}) 15 \mathrm{~min}$ after addition.

As a general trend, the fluorogenic response in S1-AChE selectivity terms was slightly better than that observed for S2AChE. This fact is directly related with the strong coordinating ability of $\mathbf{P} \mathbf{2}$ with AChE compared with $\mathbf{P 1}$. As seen in Figure 7, neostigmine, pyridostigmine, DFP and paraoxon induced the most marked rhodamine $B$ release from both materials. This observation is clearly related with the fact that these chemicals display the highest affinities to the AChE enzyme. In addition, acetylcholine and acetylthiocholine were able to induce a moderate rhodamine B release (higher for S2-AChE than for S1AChE), whereas OP1-OP5 induced a very poor payload delivery, which was tentatively ascribed to their low affinity to the AChE enzyme.

The results shown in Figure 7 suggest that S1-AChE and S2-AChE might be used for the selective fluorogenic detection of a certain chemical compound in a family of related derivatives. For instance, it is noteworthy that from all the tested nerve agent simulants, only DFP induced remarkable pore opening in both nanoparticles, whereas the response obtained with the DCP and DCNP simulants was much weaker. This fact indicates a possible use of S1-AChE and S2-AChE for the selective fluorogenic sensing of DFP. ${ }^{[33]}$ Moreover it is also of interest that both nanoparticles were able to fluorimetrically differentiate between paraoxon and parathion. Paraoxon induced marked rhodamine $B$ release, whereas the parathion response was weaker. The selective detection of paraoxon is interesting because this toxic chemical is quickly produced by air-induced parathion oxidation. ${ }^{[43]}$

\section{Conclusions}

To summarize, we report herein the preparation of two different mesoporous silica nanoparticles loaded with rhodamine B (as a model fluorophore) and capped with AChE through the formation of supramolecular complexes with two grafted derivatives of well-known enzyme inhibitors (pyridostigmine and neostigmine). Both nanoparticles remained closed and a poor rhodamine B release was observed. However in the presence of neostigmine and DFP, AChE was detached from the nanoparticle surface with the subsequent rhodamine $B$ release. The amount of rhodamine $B$ release clearly related with the affinity of the inhibitor to AChE's active sites; i.e. the better the affinity to the enzyme, the smaller the quantity needed to induce AChE detachment. It is also proposed that these capped nanoparticles could be used in sensing protocols because they are able to differentiate between DFP and other nerve agent simulants (e.g., DCP and DCNP). Paraoxon can also be differentiated from its precursor parathion. These sensing features open up the possibility of using these, or similar nanoparticles, to design chromo-fluorogenic probes for these chemical species. Moreover in a wider context, the results presented herein may pave a new way to develop MSNs-based sensing systems. The approach we have followed is general and similar materials capped with other well-known enzymes can be developed to obtain a family of gated systems that can be selectively opened in the presence of inhibitors of target enzymes.

\section{Experimental Section}

General techniques: Powder X-ray diffraction (PXRD), thermogravimetric analyses (TGA), elemental analyses, transmission electron microscopy (TEM), $\mathrm{N}_{2}$ adsorption-desorption, UV-visible (UV-vis) and fluorescence spectroscopy were employed to characterize the synthesized materials. PXRD measurements were taken by a D8 Advance diffractometer using CuKa radiation (Philips, Amsterdam, The Netherlands). Thermogravimetric analyses were carried out on a TGA/SDTA 851e balance (Mettler Toledo, Columbus, OH, USA) in an oxidizing atmosphere (air, $80 \mathrm{~mL} \mathrm{~min}^{-1}$ ) with a heating program: gradient of $393-1273 \mathrm{~K}$ at $10^{\circ} \mathrm{C} \mathrm{min}^{-1}$, followed by an isothermal heating step at $1273^{\circ} \mathrm{C}$ for $30 \mathrm{~min}$. The TEM images were obtained with a $100 \mathrm{kV}$ CM10 microscope (Philips). $\mathrm{N}_{2}$ adsorption-desorption isotherms were recorded with a Tristar II Plus automated analyzer (Micromeritics, Norcross, GA, USA). Samples were degassed at $120^{\circ} \mathrm{C}$ in vacuum overnight. Specific surface areas were calculated from the adsorption data within the low pressure range using the Brunauer, Emmett and Teller (BET) model. Pore size was determined following the Barret, Joyner and Halenda (BJH) method. Fluorescence spectroscopy measurements were taken on a Felix 32 Analysis, version 1.2 (Build 56, Photon Technology International, Birmingham, NJ, USA) and by a JASCO FP-8500 spectrophotometer.

Chemicals: Tetraethylorthosilicate (TEOS), n-cetyltrimethylammonium bromide (CTAB), sodium hydroxide, (3-isocyanatopropyl)triethoxysilane, 3-hydroxypyridine, 3-(dimethylamino)phenol, methylene iodide, triethylamine, rhodamine B, tris(hidroxymethyl)aminomethane (TRIS), hydrochloric acid, neostigmine bromide, pyridostigmine bromide, parathion, paraoxon, acetylcholine, acetylthiocholine, 
diisopropylfluorophosphate (DFP), diethyl chlorophosphate (DCP), diethyl cyanophosphonate (DCNP), dimethylmethyl phosphonate (OP-1), diethyl (2-cyanoethyl) phosphonate (OP-2), diethyl (methylthiomethyl) phosphonate (OP-3), dimethyl chlorothiophosphate (OP-4) and ethyl dichlorophosphate (OP-5) were purchased from Sigma-Aldrich química (Madrid, Spain). All the products were used as received.

Synthesis of mesoporous silica nanoparticles: $\mathrm{NaOH}\left(2.00 \mathrm{~mol} \mathrm{~L}^{-1}\right.$, $3.5 \mathrm{~mL})$ was added to a solution of CTAB $(1.00 \mathrm{~g}, 2.74 \mathrm{mmol})$ in deionized $\mathrm{H}_{2} \mathrm{O}(480 \mathrm{~mL})$. The solution temperature was adjusted to $80^{\circ} \mathrm{C}$ and then TEOS $\left(5.00 \mathrm{~mL}, 2.57 \times 10^{-2} \mathrm{~mol}\right.$ ) was added drop-wise to the surfactant mixture. The mixture was stirred for $2 \mathrm{~h}$ to give a white precipitate. The solid was isolated by centrifugation and washed with deionized $\mathrm{H}_{2} \mathrm{O}$ and $\mathrm{EtOH}$, and then dried at $60^{\circ} \mathrm{C}$ for $12 \mathrm{~h}$ to give MCM41. In order to remove the template phase, nanoparticles were calcined at $550^{\circ} \mathrm{C}$ in an oxidizing atmosphere.

Synthesis of P1: 3-hydroxypyridine (1a, $0.5 \mathrm{~g}, 5.26 \mathrm{mmol}$ ) was dissolved in $\mathrm{CH}_{3} \mathrm{CN}(20 \mathrm{~mL})$ and then (3-isocyanatopropyl)triethoxysilane (1b, $1.3 \mathrm{~mL}, 5.26 \mathrm{mmol}$ ) was added to the solution. A catalytic amount of triethylamine $(110 \mu \mathrm{L})$ was added. The mixture was kept under stirring at room temperature for $4 \mathrm{~h}$. Intermediate product $1 \mathrm{c}$ was isolated by evaporating the solvent in a rotary evaporator. In the final step, $1 \mathrm{c}(2.1 \mathrm{~g}$, $5.26 \mathrm{mmol}$ ) was dissolved in $\mathrm{CH}_{3} \mathrm{CN}(15 \mathrm{~mL})$ and reacted with methylene iodide (3.3 mL, $52 \mathrm{mmol}$ ) for $20 \mathrm{~h}$. Final product P1 $(1.03 \mathrm{~g}, 4.95 \mathrm{mmol}$, 94\%) was obtained by evaporating the solvent and methylene iodide using a rotary evaporator. ${ }^{1} \mathrm{H} \mathrm{NMR}\left(400 \mathrm{MHz}, \mathrm{CDCl}_{3}\right) \delta 9.09(\mathrm{br} \mathrm{m}, 1 \mathrm{H})$, $9.07(\mathrm{~s}, 1 \mathrm{H}), 8.33(\mathrm{dd}, 1 \mathrm{H}), 8.10(\mathrm{t}, 1 \mathrm{H}), 6.31$ (br s, 1H), $4.68(\mathrm{~s}, 3 \mathrm{H}), 3.84$ (q, 6H), $3.29(\mathrm{t}, 2 \mathrm{H}), 1.75(\mathrm{~m}, 2 \mathrm{H}), 1.24(\mathrm{t}, 9 \mathrm{H}), 0.69(\mathrm{t}, 2 \mathrm{H}) .{ }^{13} \mathrm{C} \mathrm{NMR}$ $\left(101 \mathrm{MHz}, \mathrm{CDCl}_{3}\right) \delta 151.5,150.7,138.9,137.8,128.6,128.2,58.6,50.1$, 43.9, 22.7, 18.3, 7.7. HRMS-El m/z: calcd for $\mathrm{C}_{9} \mathrm{H}_{21} \mathrm{NO}_{3} \mathrm{Si} 219.1291$; found: $219.1112\left(\left(\mathrm{CH}_{3} \mathrm{CH}_{2} \mathrm{O}\right)_{3} \mathrm{Si}\left(\mathrm{CH}_{2}\right)_{3} \mathrm{~N}\right)$, calcd for $\mathrm{C}_{6} \mathrm{H}_{8} \mathrm{NO}^{+}$110.0606; found: $110.0598\left(\mathrm{HO}-\mathrm{C}_{5} \mathrm{H}_{4} \mathrm{~N}-\mathrm{CH}_{3}{ }^{+}\right)$.

Synthesis of P2: 3-(dimethylamino)phenol (2a, $0.5 \mathrm{~g}, 3.64 \mathrm{mmol}$ ) was dissolved in $\mathrm{CH}_{3} \mathrm{CN}(20 \mathrm{~mL})$ and then (3-isocyanatopropyl)triethoxysilane $(\mathbf{2 b}, 0.9 \mathrm{~mL}, 3.64 \mathrm{mmol})$ was added to the solution. A catalytic amount of triethylamine $(110 \mu \mathrm{L})$ was added. The mixture was kept under stirring at room temperature for $4 \mathrm{~h}$. Intermediate product $2 \mathrm{c}$ was isolated by evaporating the solvent in a rotary evaporator. In the final step, 2c (1.56 $\mathrm{g}, 3.64 \mathrm{mmol}$ ) was dissolved in $\mathrm{CH}_{3} \mathrm{CN}(15 \mathrm{~mL})$ and reacted with methylene iodide $(3.3 \mathrm{~mL}, 52 \mathrm{mmol})$ for $20 \mathrm{~h}$. Final product $\mathbf{P} 2(1.03 \mathrm{~g}$, $2.47 \mathrm{mmol}, 68 \%$ ) was obtained by evaporating the solvent and methylene iodide using a rotary evaporator. ${ }^{1} \mathrm{H} \mathrm{NMR}\left(400 \mathrm{MHz}, \mathrm{CDCl}_{3}\right) \delta$ $7.78(\mathrm{~d} \mathrm{t}, 1 \mathrm{H}), 7.61(\mathrm{t}, 1 \mathrm{H}), 7.55(\mathrm{t}, 1 \mathrm{H}), 7.27(\mathrm{~d} \mathrm{t}, 1 \mathrm{H}), 5.69(\mathrm{~s}, 1 \mathrm{H}), 3.91$ $(\mathrm{s}, 3 \mathrm{H}), 3.77(\mathrm{q}, 6 \mathrm{H}), 3.20(\mathrm{t}, 2 \mathrm{H}), 1.66(\mathrm{~m}, 2 \mathrm{H}), 1.17(\mathrm{t}, 9 \mathrm{H}), 0.62$ (t , 3H). ${ }^{13} \mathrm{C}$ NMR $\left(101 \mathrm{MHz}, \mathrm{CDCl}_{3}\right) \delta 151.5,150.7,138.9,137.8,128.6$, 128.2, 58.6, 50.1, 43.9, 22.7, 18.3, 7.7. HRMS-El m/z: calcd for $\mathrm{C}_{19} \mathrm{H}_{35} \mathrm{~N}_{2} \mathrm{O}_{5} \mathrm{Si}^{+}$: 399.2310 ; found: 399.2419

Synthesis of S1 and S2: In a typical synthesis, the calcined MSNs (200 $\mathrm{mg})$ and rhodamine $\mathrm{B}(76.64 \mathrm{mg}, 0.16 \mathrm{mmol})$ were suspended in $\mathrm{CH}_{3} \mathrm{CN}$ $(10 \mathrm{~mL})$. The suspension was stirred at room temperature for $24 \mathrm{~h}$ in order to load the MCM-41 pores. P1 (193 mg, $0.2 \mathrm{mmol}$ ) or P2 (106 mg, $0.2 \mathrm{mmol}$ ) were then added, and the final suspension was stirred at room temperature for $5.5 \mathrm{~h}$. The resulting pink solid ( $\mathbf{S 1}$ or $\mathbf{S 2}$ ) was isolated by centrifugation, rinsed 3 times with deionized water and with $\mathrm{CH}_{3} \mathrm{CN}$ (5 $\mathrm{mL}$ ), and then dried at $38^{\circ} \mathrm{C}$ for $18 \mathrm{~h}$.

Synthesis of S1-AChE and S2-AChE: In a typical experiment S1 or S2 $(750 \mu \mathrm{g})$ was suspended in TRIS buffer $(450 \mu \mathrm{L}, 100 \mathrm{mM}, \mathrm{pH}=8.0)$ and
AChE enzyme ( $300 \mu \mathrm{L}, 2.5 \mu \mathrm{M})$ was added. The mixture was stirred for $30 \mathrm{~min}$ and then washed 3 times with TRIS buffer $(1 \mathrm{~mL}, 100 \mathrm{mM}, \mathrm{pH}=$ 8.0) to eliminate the residual dye and the unattached enzyme.

Enzyme activity assay: Acetylcholinesterase activity on S1-AChE and S2-AChE was checked by Ellman's assay. The test is based on the fact that thiols react with Ellman's reagent (5,5'-dithiobis(2-nitrobenzoic acid), DTNB) by cleaving the disulfide bond to give 2-nitro-5-thiobenzoate $\left(\mathrm{TNB}^{2-}\right)$. This $\mathrm{TNB}^{2-}$ has a characteristic yellow color that can be monitored by UV-visible spectrophotometry. Acetylthiocholine is used as the enzyme substrate which, when hydrolyzed, produces the resulting thiocholine as the thiol-containing molecule. In a typical assay, $900 \mu \mathrm{L}$ of $100 \mathrm{mM}$ sodium phosphate buffer ( $\mathrm{pH}$ 7.5), $30 \mu \mathrm{L} 10 \mathrm{mM}$ DTNB solution and $12 \mu \mathrm{L}$ of acetylthiocholine $(75 \mathrm{mM})$ were placed in a quartz cuvette. Then, $6 \mu \mathrm{L}$ of either buffer (for blank) or S1-AChE/S2-AChE nanoparticles $\left(2.7 \mathrm{mg} \cdot \mathrm{mL}^{-1}\right)$ were added. The mixture was shaken and absorbance at $412 \mathrm{~nm}$ was monitored.

Acetylcholinesterase activity on S1-AChE and S2-AChE was estimated to be $1.97 \mathrm{U} \mathrm{mg}^{-1}$ and $2.89 \mathrm{U} \mathrm{mg}^{-1}$, respectively, by applying the following formula:

$$
\frac{\text { Enzyme Units }}{\mathrm{g}}=\frac{\left(\Delta-\Delta_{\text {blank }}\right) * \mathrm{~V}_{\mathrm{T}} * \mathrm{~F}_{\mathrm{D}}}{\varepsilon_{T N B} * \mathrm{l} * \mathrm{~V}_{N P S} * C_{N P S}}
$$

where $\Delta$ is the slope of the graph $\left(\mathrm{min}^{-1}\right), V_{T}$ is the total volume in the cuvette, $\varepsilon_{\mathrm{TNB}}$ is the molar extinction of $\mathrm{TNB}^{2-}$ at $412 \mathrm{~nm}\left(13,700 \mathrm{M}^{-1} \mathrm{~cm}^{-1}\right)$, $\mathrm{I}$ is the optical path in the cuvette $(1 \mathrm{~cm}) \mathrm{V}_{\mathrm{NPs}}$ is the volume of nanoparticles added $(\mathrm{mL})$ and $\mathrm{C}_{\mathrm{NPs}}$ is the concentration of the nanoparticles suspension added $(\mathrm{g} / \mathrm{mL})$.

The release experiments of solid S1-AChE and S2-Ach in the presence of neostigmine and DFP: To investigate the gating properties of the solids, $750 \mu \mathrm{g}$ of nanoparticles were suspended in $600 \mu \mathrm{L}$ of TRIS buffer (100 mM, pH 8.0) and separated into three aliquots of $200 \mu \mathrm{L}$. Both samples were filled to a volume of $1250 \mu \mathrm{L}$ with the same buffer. Next $3 \mu \mathrm{L}$ of DFP were added to one aliquot and filled until a final volume of $1300 \mu \mathrm{L}$. For neostigmine, $50 \mu \mathrm{L}$ of solution were directly added. Simultaneously, $50 \mu \mathrm{L}$ of water (milliQ grade) were added to the remaining aliquot in each case. Both suspensions were stirred at $25^{\circ} \mathrm{C}$ for $90 \mathrm{~min}$. Aliquots of $150 \mu \mathrm{L}$ were taken at several times and centrifuged for $2 \mathrm{~min}$ at $12000 \mathrm{rpm}$ (to remove the solid) and the fluorescence of the released rhodamine $B$ was measured at $575 \mathrm{~nm}\left(\Lambda_{\mathrm{exc}}=555 \mathrm{~nm}\right)$. The same procedure was used for the release experiments carried out at $\mathrm{pH}$ 6.0 (100 mM MES buffer) and $4.0(100 \mathrm{mM}$ acetic acid/sodium acetate buffer).

The calibration curve of S1-AChE and S2-AChE with DFP or neostigmine: In order to carry out these experiments, $500 \mu \mathrm{g}$ of $\mathbf{S 1}$ AChE or S2-AChE were suspended in $750 \mu \mathrm{L}$ of TRIS buffer $(100 \mathrm{mM}$, $\mathrm{pH}$ 8.0) and divided into 15 aliquots of $50 \mu \mathrm{L}$ each. Several water solutions of DFP or neostigmine, which fell within a range from 0.06 to $10000 \mu \mathrm{M}$, were prepared and, instantaneously, $150 \mu \mathrm{L}$ of each solution were added to the aliquots and stirred for $15 \mathrm{~min}$. One aliquot was reserved to add $150 \mu \mathrm{L}$ of water (milliQ grade) as a blank. Then suspensions were centrifuged for $2 \mathrm{~min}$ at $12000 \mathrm{rpm}$ (to remove the solid) and the fluorescence of the released rhodamine $B$ was measured at $575 \mathrm{~nm}\left(\Lambda_{\mathrm{exc}}=555 \mathrm{~nm}\right)$

The selectivity studies with S1-AChE and S2-AChE: In order to test the selectivity of the solids, $500 \mu \mathrm{g}$ of nanoparticles were suspended in 1 $\mathrm{mL}$ of TRIS buffer (100 mM, pH 8.0) and were divided into 10 aliquots of 
$100 \mu \mathrm{L}$. Several water solutions of different organophosphorus compounds (DFP, DCP, DCNP, Pthion, Pox, OP1, OP2, OP3, OP4, OP5, $A C h, A S C h, P G$ and $N G$ ) were prepared at a concentration of $5 \mathrm{mM}$. Next $200 \mu \mathrm{L}$ of the prepared solutions were added to each aliquot to obtain a final concentration of $1000 \mathrm{ppm}$. One aliquot was reserved to add $200 \mu \mathrm{L}$ of water (milliQ grade) as a blank. After 15 min of stirring, samples were centrifuged for $2 \mathrm{~min}$ at $12000 \mathrm{rpm}$ (to remove the solid) and the fluorescence of the released rhodamine $B$ was measured at 575 $\mathrm{nm}\left(\lambda_{\mathrm{exc}}=555 \mathrm{~nm}\right)$.

\section{Acknowledgements}

Financial support from the Spanish Government and FEDER funds (Project MAT2015-64139-C4-1-R, AGL2015-70235-C2-2R) and the Generalitat Valencia (Project PROMETEOII/2014/047) is gratefully acknowledged. LI. P. is grateful to the Universitat Politécnica de Valencia for his grant.

Keywords: acetylcholinesterase $\cdot$ enzyme inihibitors $•$ enzymecapped nanoparticles $\cdot$ neostigmine $\cdot$ DFP

[1] S. Alberti, G. J. A. A. Soler-Illia, O. Azzaroni, Chem. Commun. 2015 51, 6050-6075

[2] E. Aznar, M. Oroval, L. Pascual, J. R. Murguía, R. Martínez-Máñez, F. Sancenón, Chem. Rev. 2016, 116, 561-718.

C. Coll, A. Bernardos, R. Martínez-Máñez, F. Sancenón, Acc. Chem. Res. 2013, 46, 339-349.

[4] I. I. Slowing, B. G. Trewyn, S. Giri, V. S. Y. Lin, Adv. Funct. Mater.2007, 17, 1225-1236

[5] X. Yang, X. Liu, Z. Liu, F. Pu, J. Ren, X. Qu, Adv. Mater. 2012, 24, 2890-2895.

[6] A. B. Descalzo, R. Martínez-Máñez, F. Sancenón, K. Hoffmann, K. Rurack, Angew. Chem. Int. Ed. 2006, 45, 5924-5948.

[7] J. S. Beck, J. C. Vartuli, W. J. Roth, M. E. Leonowicz, C. T. Kresge, K. D. Schmitt, C. T. W. Chu, D. H. Olson, E. W. Sheppard, S. B. McCullen, J. B. Higgins, J. L. Schlenker, J. Am. Chem. Soc. 1992 114, 10834-10843.

[8] G. S. Attard, J. C. Glyde, C. G. Göltner, Nature 1995, 378, 366-368.

[9] C. T. Kresge, M. E. Leonowicz, W. J. Roth, J. C. Vartuli, J. S. Beck, Nature 1992, 359, 710-712.

[10] Q. Cai, Z.-S. Luo, W.-Q. Pang, Y.-W. Fan, X.-H. Chen, F.-Z. Cui, Chem. Mater. 2001, 13, 258-263.

[11] H. B. S. Chan, P. M. Budd, T. Naylor, J. Mater. Chem. 2001, 11 951-957.

[12] Z. Li, J. C. Barnes, A. Bosoy, J. F. Stoddart, J. I. Zink, Chem. Soc. Z. Li, J. C. Barnes, A. Bosoy, J. F. Stoddart, J. I. Zink, Chem. Soc.
Rev. 2012, 41, 2590.

[13] I. I. Slowing, B. G. Trewyn, S. Giri, V. S. -Y. Lin, Adv. Funct. Mater. 2007, 17, 1225-1236.

[14] M. Vallet-Regí, F. Balas, D. Arcos, Angew. Chem. Int. Ed. 2007, 46 7548-7558.

[15] F. Sancenón, L. Pascual, M. Oroval, E. Aznar, R. Martínez-Máñez, ChemistryOpen 2015, 4, 418-437.

[16] K. Radhakrishnan, J. Tripathy, D. P. Gnanadhas, D. Chakravortty, A. M. Raichur, RSC Adv. 2014, 4, 45961-45968.

[17] K. Patel, S. Angelos, W. R. Dichtel, A. Coskun, Y. W. Yang, J. I. Zink, J. F. Stoddart, J. Am. Chem. Soc. 2008, 130, 2382-2383.

[18] C. de la Torre, L. Mondragón, C. Coll, F. Sancenón, M. D. Marcos, R. Martínez-Máñez, P. Amorós, E. Pérez-Payá, M. Orzaez, Chem. Eur. J. 2014, 20, 15309-15314.

[19] A. Agostini, L. Mondragón, L. Pascual, E. Aznar, C. Coll, R. Martínez-Máñez, F. Sancenón, J. Soto, M. D. Marcos, P. Amorós, A M. Costero, M. Parra, S. Gil, Langmuir 2012, 28, 14766-14776.

[20] I. Candel, E. Aznar, L. Mondragón, C. de la Torre, R. MartínezMáñez, F. Sancenón, M. D. Marcos, P. Amorós, C. Guillem, E. Pérez-Payá, A. M. Costero, S. Gil, M. Parra, Nanoscale 2012, 4 7237-7245.

[21] N. Mas, A. Agostini, L. Mondragón, A. Bernardos, F. Sancenón, M.
D. Marcos, R. Martínez-Máñez, A. M. Costero, S. Gil, M. MerinoSanjuan, P. Amorós, M. Orzaez, E. Pérez-Payá, Chem. Eur. J. 2013, 19, 1346-1356.

[22] A. Bernardos, E. Aznar, M. D. Marcos, R. Martínez-Máñez, F. Sancenón, J. Soto, J. M. Barat, P. Amorós, Angew. Chem. Int. Ed. 2009, 48, 5884-5887.

[23] Y. F. Zhu, W. J. Meng, N. Hanagata, Dalton Trans .2011, 40, 10203-10208.

[24] A. Agostini, L. Mondragón, A. Bernardos, R. Martínez-Máñez, M. D. Marcos, F. Sancenón, J. Soto, A Costero, C. Manguan-García, R. Perona, M. Moreno-Torres, R. Aparicio-Sanchis, J. R. Murguía, Angew. Chem. Int. Ed. 2012, 51, 10556-10560.

[25] E. Aznar, R. Villalonga, C. Giménez, F. Sancenón, M. D. Marcos, R Martínez-Máñez, P. Diez, J. M. Pingarron, P. Amorós, Chem. Commun. 2013, 49, 6391-6393.

[26] M. J. Chen, C. S. Huang, C. S. He, W. P. Zhu, Y. F. Xu, Y. F. Lu, Chem. Commun. 2012, 48, 9522-9524.

[27] (a) P. Díez, A. Sanchez, M. Gamella, P. Martínez-Ruiz, E. Aznar, C. de la Torre, J. R. Murguia, R. Martínez-Máñez, R. Villalonga, J. M. Pingarrón, J. Am. Chem. Soc. 2014, 136, 9116-9123; (b) P. Díez, A Sánchez, C de la Torre, M. Gamella, P. Martínez-Ruíz, E. Aznar, R. Martínez-Máñez, J. M. Pingarrón, R. Villalonga, ACS Appl. Mater. Interfaces 2016, 8, 7657-7665.

[28] X. J. Yang, F. Pu, C. E. Chen, J. S. Ren, X. G. Qu, Chem. Commun. 2012, 48, 11133-11135.

[29] S. Datz, C. Argyo, M. Gattner, V. Weiss, K. Brunner, J. Bretzler, C. von Schirnding, A. A. Torrano, F. Spada, M. Vrabel, H. Engelke, C. Bräuchle, T. Carrel, T. Bein, Nanoscale 2016, 8, 8101-8110.

[30] (a) X. X Sun, Y. N. Zhao, V. S. -Y. Lin, I. I. Slowing, B. G. Trewyn, J. Am. Chem. Soc. 2011, 133, 18554-18557; (b) P. Liu, X. Wang, K Hiltunen, Z. Chen, ACS Appl. Mater. Interfaces 2015, 7, 26811 26818; (c) X. Wang, P. Liu, Z. Chen, J. Shen, RSC Adv. 2016, 6, 25480-25484.

[31] (a) H. P. Rim, K. H. Min, H. J. Lee, S. Y. Jeong, S. C. Lee, Angew. Chem. Int. Ed. 2011, 50, 8853-8857; (b) W. Zhao, H. Zhang, Q. He Y. Li, J. Gu, L. Li, H. Li, J. Shi, Chem. Commun. 2011, 47, 9459 9461.

[32] See for example: (a) S. El Sayed, M. Mllani, C. Milanese, M. Licchelli, R. Matínez-Máñez, F. Sancenón, Chem. Eur. J.2016, 22 Licchelli, R. Matínez-Máñez, F. Sancenón, Chem. Eur. J.2016, 22 , Sancenón, R. Martínez-Máñez, Langmuir 2016, 32, 8507-8515; (c) C. Giménez, E. Climent, E. Aznar, R. Martínez-Máñez, F. Sancenón, M. D. Marcos, P. Amorós, K. Rurack, Angew. Chem. Int Ed. 2014, 53, 12629-12633; (d) C. de la Torre, A. Agostini, L. Mondragón, M. Orzaez, F. Sancenón, R. Martínez-Máñez, M. D. Marcos, P. Amorós, E. Pérez- Payá, Chem. Commun. 2014, 50, 3184-3186; (e) M. Oroval, E Climent, C Coll, R Eritja, A Aviñó, M. D Marcos, F. Sancenón, R. Martínez-Máñez, P. Amorós, Chem. Commun. 2013, 49, 5480-5482.

[33] LI. Pascual, S. El Sayed, R. Martínez-Máñez, A. M. Costero, S. Gil, P. Gaviña, F. Sancenón, Org. Lett. 2016, 18, 5548-5551.

[34] M. Comes, G. Rodríguez-López, M. D. Marcos, R. Martínez-Máñez, F. Sancenón, J. Soto, L. A. Villaescusa, P. Amorós, D. Beltrán, Angew. Chem. Int. Ed. 2005, 44, 2918-2922.

[35] D. E. Lorke, M. Y. Hasan, K. Arafat, K. Kuča, K. Musilek, A. Schmitt, G. A. Petroianu, J. Appl. Toxicol. 2008, 28, 422-429.

[36] H. P. Rang, M. Dale, J. M. Ritter, R. J. Flower, G. Henderson, Rang \& Dale's Pharmacology, Elsevier Churchill Livingstone, London, England, 2015.

[37] G. Petroianu, F. Kühn, C. Thyes, V. Ewald, A. Missler, J. Appl. Toxicol. 2003, 23, 75-79.

[38] S. J. A. Grove, J. Kaur, A. W. Muir, E. Pow, G. J. Tarver, M.-Q. Zhang, Bioorg. Med. Chem. Lett. 2002, 12, 193-196.

[39] W. S. Augerson in Chemical and Biological Warfare Agents(Ed. W.S. Augerson), RAND, 2000, pp. 99-189.

[40] J. C. Dacre in Cholinesterases Fundamental and Applied Aspects (Eds.: M. Brzin, E.A. Barnard, D. Sket), Walter De Gruyter, New York, 1984, pp. 415-126.

[41] S. Royo, R. Martínez-Máñez, F. Sancenón, A. M. Costero, M. Parra S. Gil, Chem. Commun. 2007, 4839-4847.

[42] (a) C. Fan, L. Tsui, M. -C. Liao, Chemosphere2011, 82, 229-236; (b) I. S. Fonsgaard, Int. J. Environ. Anal. Chem. 1995, 58, 231-245.

See for example: (a) J. Turan, M. Kesik, S. Soylemez, S. Goker, S. Coskun, H. E. Unalan, L. Toppare, Sens. Act. B. Chem. 2016, 228 278-286; (b) R. Funari, B.Della Ventura, R. Carrieri, L. Mora, E. Lahoz, F. Gesuele, C. Altucci, R. Velotta, Biosen. Bioelectron. 2015 67, 224-229; (c) G. Fu, W. Chen, X. Yue, X. Jiang, Talanta 2013 103, 110-115; (d) K. Wang, L. Wang, W. Jiang, J. Hu, Talanta 2011, 84, 400-405. 
Table of Contents

\section{FULL PAPER}

Mesoporous silica nanoparticles capped with acetylcholinesterase enzyme were prepared and characterized. The enzyme was detached from the surface of nanoparticles in the presence of its inhibitors with a subsequent fluorophore release.
LI. Pascual, S. El Sayed, R. MartínezMáñez* and F. Sancenón

Page No. - Page No.

Acetylcholinesterase-capped mesoporous silica nanoparticles operated by inhibitors competition 